Acta Theriologica $37(1-2): 1-13,1992$.

PL ISSN $0001-7051$

\title{
Allozyme evolution and the molecular clock in the Lagomorpha
}

\author{
Martin GRILLITSCH, Günther B. HARTL, Franz SUCHENTRUNK \\ and Rudolf WILLING
}

Grillitsch M., Hartl G. B., Suchentrunk F. and Willing R. 1992. Allozyme evolution and the molecular clock in the Lagomorpha. Acta theriol. 37: 1-13.

In order to provide a scale of genetic distances in the Lagomorpha, biochemicalsystematic relationships among Lepus europaeus, Lepus timidus, Oryctolagus cuniculus (Leporidae) and Ochotona rufescens (Ochotonidae) were examined by horizontal starch gel electrophoresis of 38 isozyme systems. Nei's (1978) genetic distances were calculated over 58 presumptive structural loci and used for the construction of numerical dendrograms. The stability of clusters was examined by the jackknife method and by comparison to a Hennigian cladogram. All these procedures revealed a constant picture of lagomorph relationships, which is in accordance with the conclusions drawn from other evidence. Divergence times were estimated using two fundamentally different approaches. They were in good agreement with paleontological data $(0.49 \mathrm{myr}$ between the Lepus species, $3.65 \mathrm{myr}$ between Lepus and Oryctolagus, $37.5 \mathrm{myr}$ between Leporidae and Ochotonidae), but only when calculated in different ways at low and at high taxonomic levels. The results suggest a temporal acceleration of the rate of allozyme evolution in the Leporidae due to rapid adaptive radiation of biochemically highly polymorphic taxa.

Forschungsinstitut für Wildtierkunde und Ökologie der Veterinärmedizinischen Universität Wien, Savoyenstraße 1, A-1160 Vienna, Austria

Key words: Lagomorpha, enzyme electrophoresis, genetic distances, phylogenetic trees, molecular clock

\section{Introduction}

During the last two decades, protein electrophoretic data were increasingly used to evaluate biochemical-systematic relationships in mammals. However, apart from rodents and primates, which are favoured groups in all kinds of systematic investigations (the former probably because access to all kifis of material is comparatively easy, the latter because of their relationship to man), only two orders were examined more extensively for biochemical-systematic relationships above the level of congeneric species or closely related genera: The Artiodactyla (e.g. Baccus et al. 1983, Hartl et al. 1988a, 1990a, b; Georgiadis et al. 1990, Randi et al. 1991) and the Carnivora (e. g. Simonsen 1982, Wayne and O’Brien 1987, Hartl et al. 1988b, Goldman et al. 1989, Taylor et al. 1991). In some of these surveys, unequal rates of allozyme evolution were detected among taxa, 
which can be interpreted either as the result of rapid cladogenesis (comp. Bonhomme et al. 1985, Hartl et al. 1990a, b) or by an increased rate of anagenetic change due to other factors than a previous radiation (Taylor et al. 1991, Hartl et al. 1992).

In the Lagomorpha, biochemical-systematic data are particularly scarce: The electrophoretic studies of Vergnes et al. (1974 - Ochotona rufescens / Oryctolagus cuniculus) and of Robinson and Osterhoff (1983 - Lepus spp. / Pronolagus spp.) are severely restricted in the numbers of isozyme loci examined. Genetic distance estimates are available only for three Lepus species from Spain (Bonhomme et al. 1986 - 42 loci) and for Oryctolagus cuniculus and Lepus europaeus (Hartl 1987 38 loci), which are based on very different sets of isozymes and are therefore not fully comparable (see Hartl et al. 1990a). It is the aim of the present paper, to provide a spectrum of genetic distances in the Lagomorpha, ranging from local populations over closely related species and genera up to the level of families. Based on a large number of loci screened, rates of enzyme evolution are evaluated and examined for their influence on both the reconstruction of phylogenetic relationships and the calculation of divergence times in the Lagomorpha.

\section{Material and methods}

Biochemical-systematic relationships among the brown hare (Lepus europaeus), the mountain hare (Lepus timidus), the old world rabbit (Oryctolagus cuniculus) (Leporidae), and the pika (Ochotona rufescens) (Ochotonidae) were examined, whereby the horse, Equus przewalskii f. caballus served as an outgroup. For direct comparison 6 brown hares (heterozygous carriers of the various allozymes detected by Hartl et al., in preparation), 4 mountain hares (culled in Carinthia, Austria), 4 rabbits (heterozygous carriers of the various allozymes detected by Peterka and Hartl 1992), 4 pikas (breed of the Laboratoire de Pharmacologie et de Toxicologie Fondamentales, Toulouse, France) and 2 horses (slaughter-house St. Marx, Vienna) were used. Allele frequencies in the brown hare are based on 469 specimens from Austria screened by Hartl et al. (in preparation), in the rabbit on 204 specimens screened by Peterka and Hartl (1992).

Using routine electrophoretic techniques (Hartl and Höger 1986, Grillitsch 1990) 38 isozyme systems were screened. Enzyme names, abbreviations, E.C. numbers, tissues, buffer systems and references for staining procedures are given in Table 1.

The interpretation of electrophoretic patterns, the assessment of homology of the respective isozymes and the distinction between mitochondrial and cytosolic isozymes were performed according to Hartl et al. (1990a). The statistical evaluation of the data followed the various methods reviewed and compared empirically in the same paper.

\section{Results}

Screening of 38 isozyme systems in the Lagomorpha revealed a total of 62 presumptive structural loci. The alleles and their frequencies detected in the various taxa are listed in Table 2.

Genetic distances, calculated according to Nei (1978), are given in Table 3 since four of the loci (Pk-2, Pgm-3, Fdp-2, and Gpi-1) were not scorable in all taxa, 
Table 1: Isozyme systems screened (abbreviation and E.C. number in parentheses), tissues $(\mathrm{L}=$ liver, $\mathrm{K}=$ kidney, $\mathrm{H}=$ heart $)$, buffer systems $(\mathrm{P}=$ continuous phosphate buffer, $\mathrm{pH} 7.4, \mathrm{TM}=$ continuous tris-maleate buffer, $\mathrm{pH} 7.4$ - Csaikl et al. $1980, \mathrm{TC}=$ continuous tris-citrate buffer, $\mathrm{pH} 8.0$-Manlove et al. 1975) and references for staining procedures $(1=$ Thorup et al. 1961, 2 = Shaw and Prasad 1970, 3 = Brewer and Sing 1970, 4 = Selander et al. $1971,5=$ Siciliano and Shaw 1976, 6 = Harris and Hopkinson 1976, 7 = Qavi and Kit 1980, 8 = Richardson et al. 1986) used in the present study.

\begin{tabular}{|c|c|c|c|}
\hline Isozyme system & Tissue & Buffer & Stain \\
\hline$\alpha$-glycerophosphate dehydrogenase (GDC, E.C. 1.1.1.8) & L & $\mathrm{TC}$ & 2 \\
\hline sorbitol dehydrogenase (SDH, E.C. 1.1.1.14) & $\mathrm{L}$ & $\mathrm{TC}$ & 2 \\
\hline lactate dehydrogenase (LDH, E.C. 1.1.1.27) & $\mathrm{K}$ & $\mathbf{P}$ & 4 \\
\hline malate dehydrogenase (MDH or MOR, E.C. 1.1.1.37) & $\mathrm{K}$ & $\mathrm{TC}$ & 4 \\
\hline malic enzyme (ME or MOD, E.C. 1.1.1.40) & $\mathrm{K}$ & TM & 5 \\
\hline isocitrate dehydrogenase (IDH, E.C. 1.1.1.42) & $\mathrm{K}$ & $\mathrm{TC}$ & 4 \\
\hline 6-phosphogluconate dehydrogenase (PGD, E.C. 1.1.1.44) & $\mathrm{K}$ & $\mathrm{P}$ & 4 \\
\hline glucose dehydrogenase (GDH, E.C. 1.1.1.47) & $\mathrm{L}$ & TC & 6 \\
\hline glucose-6-phosphate dehydrogenase (GPD, E.C. 1.1.1.49) & $\mathrm{K}$ & $\mathrm{TC}$ & 4 \\
\hline glyceraldehyde-3-phosphate dehydrogenase (GAPDH, E.C. 1.2.1.12) & $\mathrm{L}$ & $\mathrm{TC}$ & 5 \\
\hline xanthine dehydrogenase $(\mathrm{XDH}$, E.C. 1.2 .3 .2$)$ & $\mathrm{L}$ & TC & 2 \\
\hline glutamate dehydrogenase (GLUD, E.C. 1.4.1.3) & $\mathrm{L}$ & TC & 3 \\
\hline NADH-diaphorase (DIA, E.C. 1.6.2.2) & $\mathrm{H}$ & TC & 6 \\
\hline catalase (CAT or CE, E.C. 1.11.1.6) & $\mathrm{K}$ & TM & 1 \\
\hline superoxide dismutase (SOD, E.C. 1.15.1.1) & $\mathrm{K}$ & $\mathrm{P}$ & 4 \\
\hline purine nucleoside phosphorylase (NP, E.C. 2.4.2.1) & $\mathrm{K}$ & $\mathrm{P}$ & 6 \\
\hline aspartate aminotransferase (AAT or GOT, E.C. 2.6.1.1) & $\mathrm{K}$ & TC & 4 \\
\hline glutamate pyruvate transaminase (GPT, E.C. 2.6 .1 .2 ) & $\mathrm{L}$ & TC & 6 \\
\hline hexokinase (HK, E.C. 2.7.1.1) & $\mathrm{H}$ & $\mathrm{TC}$ & 6 \\
\hline pyruvate kinase (PK, E.C. 2.7.1.40) & $\mathrm{H}$ & TC & 5 \\
\hline phosphoglycerate kinase (PGK, E.C. 2.7.2.3) & $\mathrm{H}$ & $\mathrm{TC}$ & 5 \\
\hline creatine kinase (CK, E.C. 2.7.3.2) & $\mathrm{H}, \mathrm{K}$ & $\mathrm{TC}$ & 2 \\
\hline adenylate kinase (AK, E.C. 2.7.4.3) & $\mathrm{H}, \mathrm{K}$ & $\mathrm{TC}$ & 5 \\
\hline phosphoglucomutase (PGM, E.C. 2.7.5.1) & $\mathrm{K}$ & $\mathrm{P}$ & 6 \\
\hline esterases (ES, E.C. 3.1.1.1) & $\mathrm{K}$ & $\mathrm{P}$ & 2,6 \\
\hline acid phosphatase (ACP, E.C. 3.1 .3 .2 ) & $\mathrm{K}$ & $\mathrm{TC}$ & 2 \\
\hline fructose-1,6-diphosphatase (FDP, E.C. 3.1.3.11) & $\mathrm{K}$ & TC & 8 \\
\hline B-galactosidase (ß-GAL, E.C. 3.2 .1 .23 ) & $\mathrm{L}$ & $\mathrm{P}$ & 6 \\
\hline B-glucu ronidase ( $\beta$-GUS, E.C. 3.2.1.31) & $\mathrm{L}$ & $\mathrm{P}$ & 6 \\
\hline peptidases (PEP, E.C. 3.4.11) & $\mathrm{K}$ & $\mathrm{P}$ & 5 \\
\hline aminoacylase 1 (ACY-1, E.C. 3.5 .1 .14 ) & $\mathrm{L}$ & TC & 7 \\
\hline guanine deaminase (GDA, E.C. 3.5 .4 .3 ) & $\mathrm{L}$ & TC & 6 \\
\hline adenosine deaminase (ADA, E.C. 3.5 .4 .4$)$ & $\mathrm{L}, \mathrm{H}$ & $\mathrm{TC}$ & 6 \\
\hline aldolase (ALDO, E.C. 4.1.2.13) & $\mathrm{H}$ & $\mathrm{TC}$ & 6 \\
\hline fumarate hydratase (FH, E.C. 4.2.1.2) & $\mathrm{H}$ & $\mathrm{TC}$ & 5 \\
\hline aconitase (ACO, E.C. 4.2 .1 .3 ) & $\mathrm{K}$ & $\mathrm{TC}$ & 6 \\
\hline mannosephosphate isomerase (MPI, E.C. 5.3.1.8) & $\mathrm{K}$ & $\mathrm{P}$ & 5 \\
\hline glucose phosphate isomerase (GPI, E.C. 5.3.1.9) & $\mathrm{K}$ & $\mathrm{P}$ & 4 \\
\hline
\end{tabular}


Table 2. Alleles detected in four lagomorph taxa (in the case of polymorphism frequencies are given in parentheses). L. e. = Lepus europaeus, L. $t .=$ Lepus timidus, Or. $c .=$ Oryctolagus cuniculus, O. $r$. = Ochotona rufescens, E. p. = Equus przewalskii. $\mathrm{X}=$ locus not scorable.

\begin{tabular}{|c|c|c|c|c|c|}
\hline Locus & L.e. & L. $t$. & Or.c. & O. $r$. & E. $p$. \\
\hline 1 & 2 & 3 & 4 & 5 & 6 \\
\hline$G d c$ & a & a & b & $\mathrm{c}$ & $\mathrm{d}$ \\
\hline Sdh & $\begin{array}{c}\mathrm{a}, \mathrm{b} \\
(.996 / .004)\end{array}$ & $\mathrm{b}$ & c & $\mathrm{d}$ & e \\
\hline$L d h-1$ & a & a & a & $\mathrm{b}$ & c \\
\hline$L d h-2$ & $\begin{array}{c}\mathrm{a}, \mathrm{b} \\
(.997 / .003)\end{array}$ & a & c & $\mathrm{d}$ & a \\
\hline$M d h-1$ & a & $\mathbf{a}$ & $\mathrm{b}$ & $\mathrm{b}$ & c \\
\hline$M d h-2$ & $\begin{array}{c}\mathrm{a}, \mathrm{b} \\
(.986 / .014)\end{array}$ & a & a & c & d \\
\hline$M e-1$ & a & a & b & b & $\mathrm{c}$ \\
\hline $\mathrm{Me}-2$ & a & a & a & $\mathrm{b}$ & c \\
\hline Idh-1 & a & a & a & $\mathrm{b}$ & a \\
\hline$I d h-2$ & $\begin{array}{c}\mathrm{a}, \mathrm{b}, \mathrm{c} \\
(.959 / .033 / .008)\end{array}$ & a & a & c & d \\
\hline Pgd & $\begin{array}{c}\mathrm{a}, \mathrm{b}, \mathrm{c}, \mathrm{d}, \mathrm{e} \\
(.934 / .025 / .006 / .015 / .020)\end{array}$ & a & $\begin{array}{c}\mathrm{a}, \mathrm{f} \\
(.983 / .017)\end{array}$ & $\mathrm{g}$ & $\mathrm{h}$ \\
\hline Gdh-1 & a & a & a & a & b \\
\hline Gdh-2 & a & a & $\mathrm{b}$ & c & d \\
\hline Gpd & $\mathbf{a}$ & a & a & $\mathrm{b}$ & $\mathrm{b}$ \\
\hline Gapdh & a & a & $\mathrm{b}$ & a & a \\
\hline$X d h$ & a & a & $\mathrm{b}$ & a & c \\
\hline Glud & a & a & a & a & a \\
\hline Dia-1 & a & a & a & a & $\mathrm{b}$ \\
\hline Dia-2 & a & a & b & c & d \\
\hline Cat & a & a & $\mathrm{b}$ & b & c \\
\hline Sod-1 & a & a & a & $\mathrm{b}$ & c \\
\hline Sod-2 & a & a & $\mathrm{b}$ & a & c \\
\hline$N p$ & a & a & a & b & c \\
\hline Aat-1 & a & a & a & b & a \\
\hline Aat-2 & a & a & a & $\mathrm{b}$ & c \\
\hline$G p t$ & a & a & $\mathrm{b}$ & c & d \\
\hline$H k-1$ & a & a & a & b & c \\
\hline$H k-2$ & a & a & a & b & c \\
\hline$H k-3$ & a & a & a & b & c \\
\hline$P k-1$ & a & a & a & b & a \\
\hline$P k-2$ & a & a & $\mathrm{X}$ & b & c \\
\hline$P g k$ & a & a & a & $\mathrm{b}$ & c \\
\hline$C k-1$ & a & a & a & $\mathrm{b}$ & c \\
\hline$C k-2$ & a & a & b & a & a \\
\hline$A k-1$ & a & a & b & a & c \\
\hline$A k-2$ & a & a & b & a & c \\
\hline$A k-3$ & $a$ & a & $\mathrm{b}$ & a & c \\
\hline
\end{tabular}


Table 2 continued

\begin{tabular}{|c|c|c|c|c|c|}
\hline 1 & 2 & 3 & 4 & 5 & 6 \\
\hline$P g m-1$ & a & $\mathrm{b}$ & c & d & e \\
\hline$P g m-2$ & a & a & b & $\mathrm{b}$ & c \\
\hline$P g m-3$ & a & $a$ & $\mathrm{~b}$ & $\mathrm{X}$ & c \\
\hline Es-d & $\begin{array}{c}\mathrm{a}, \mathrm{b} \\
(.820 / .180)\end{array}$ & $\begin{array}{c}\mathrm{a}, \mathrm{b} \\
(.500 / .500)\end{array}$ & a & c & d \\
\hline$E s-I$ & $\begin{array}{c}\mathrm{a}, \mathrm{b}, \mathrm{c}, \mathrm{d} \\
(.021 / .613 / .353 / .013)\end{array}$ & $\begin{array}{c}\mathrm{a}, \mathrm{b} \\
(.125 / .875)\end{array}$ & $\begin{array}{c}\mathrm{e}, \mathrm{f} \\
(.815 / .185)\end{array}$ & g & $\mathrm{h}$ \\
\hline$F d p-1$ & $\mathrm{a}$ & a & b & $\mathrm{b}$ & c \\
\hline$F d p-2$ & a & a & $\mathrm{X}$ & a & b \\
\hline Acp-1 & a & $\mathrm{b}$ & c & d & d \\
\hline Acp-2 & a & a & b & c & d \\
\hline Acp-3 & a & a & $\mathrm{b}$ & a & c \\
\hline$\beta$-Gal & $\begin{array}{c}\text { a, b, c } \\
(.390 / .522 / .088)\end{array}$ & $\mathrm{b}$ & $\mathrm{b}$ & d & e \\
\hline$\beta$-Gus & a & $\mathrm{b}$ & a & c & a \\
\hline Pep-1 & $\mathrm{a}$ & a & $\mathrm{b}$ & c & d \\
\hline Pep-2 & $\begin{array}{c}\text { a, b, c } \\
(.799 / .193 / .008)\end{array}$ & b & d & e & f \\
\hline Acy-1 & $\begin{array}{c}\text { a, b, c } \\
(.140 / .537 / .323)\end{array}$ & b, c & c & $\begin{array}{c}\mathrm{a}, \mathrm{b} \\
(.750 / .250)\end{array}$ & $\begin{array}{c}\mathrm{b} \\
(.500 / .500)\end{array}$ \\
\hline$G d a$ & a & a & $\mathrm{b}$ & c & a \\
\hline Ada-1 & a & a & $\mathrm{b}$ & $\mathrm{b}$ & c \\
\hline Ada-2 & $\begin{array}{c}\mathrm{a}, \mathrm{b} \\
(.883 / .117)\end{array}$ & $\begin{array}{c}\text { a, b, c } \\
(.375 / .125 / .500)\end{array}$ & d & e & f \\
\hline Aldo & a & a & a & a & a \\
\hline$F h$ & a & a & a & a & b \\
\hline Aco-1 & a & a & a & $\mathrm{b}$ & $\mathrm{b}$ \\
\hline Aco-2 & a & a & a & $\begin{array}{c}\mathrm{b}, \mathrm{c} \\
(.500 / .500)\end{array}$ & a \\
\hline Mpi & $\begin{array}{c}\text { a, b, c } \\
(.980 / .018 / .002)\end{array}$ & $\begin{array}{c}\mathrm{a}, \mathrm{b} \\
(.875 / .125)\end{array}$ & $\begin{array}{c}\mathrm{d}, \mathrm{e}, \mathrm{f} \\
(.423 / .190 / .387)\end{array}$ & $\begin{array}{c}\mathrm{g}, \mathrm{h} \\
(.500 / .500)\end{array}$ & $\begin{array}{c}\mathrm{e}, \mathrm{i} \\
(.500 / .500)\end{array}$ \\
\hline Gpi-1 & a & a & a & b & $\mathrm{x}$ \\
\hline Gpi-2 & a & a & a & b & $\begin{array}{c}\mathrm{c}, \mathrm{d} \\
(.750 / .250)\end{array}$ \\
\hline
\end{tabular}

they are based on 58 loci. Phylogenetic trees, constructed according to various methods (Nei's (1978) D/UPGMA - Fig. 1, Nei's D/Fitch-Margoliash tree - Fig. 2, Hennigian cladogram - Fig. 3) are in good agreement and also the maximum parsimony method (PHYLIP-programme package, Felsenstein 1985) revealed only one solution. The stability of clusters in relation to the composition of the isozyme loci scored was examined using the jackknife method (Hartl et al. 1990a). A majority rule consensus tree, constructed from 100 Nei's (1978) D/UPGMA dendrograms (in each of which $25 \%$ of the loci were randomly omitted), revealed an identical topology in all cases. Divergence times ( $t$ ) were calculated using two 
Table 3. Genetic identities - above the diagonal - and genetic distances - below the diagonal between the lagomorph taxa examined, calculated according to Nei (1978), L. e. = Lepus europaeus, $L . t$. $=$ Lepus timidus, Or. $c$. = Oryctolagus cuniculus, O. $r .=$ Ochotona rufescens, $E . p .=$ Equus przewalskii .

\begin{tabular}{lccccc}
\hline & L.e. & L.t. & Or. $c$. & O. $r$. & E. $p$. \\
\hline L. e. & - & 0.9063 & 0.4905 & 0.2394 & 0.2059 \\
L. $t$. & 0.0984 & - & 0.4738 & 0.2386 & 0.1909 \\
Or. . & 0.7123 & 0.7469 & - & 0.1942 & 0.1246 \\
O. $r$. & 1.4297 & 1.4329 & 1.6391 & - & 0.1326 \\
E. $p$. & 1.5805 & 1.6562 & 2.0824 & 2.0204 & - \\
\hline
\end{tabular}

Table 4. Divergence times between the lagomorph taxa examined, calculated by two different methods. I = Nei (1975), II = Wayne and O'Brien (1987).

\begin{tabular}{lcc}
\hline \multirow{2}{*}{ Taxa } & \multicolumn{2}{c}{ Divergence time (myr) } \\
\cline { 2 - 3 } & Method I & Method II \\
\hline Lepus europaeus/Lepus timidus & 0.49 & 2.46 \\
Lepus/Oryctolagus & 3.65 & 18.24 \\
Leporidae/Ochotonidae & 7.50 & 37.52 \\
Lagomorpha/Perissodactyla & 9.18 & 45.87 \\
\hline
\end{tabular}

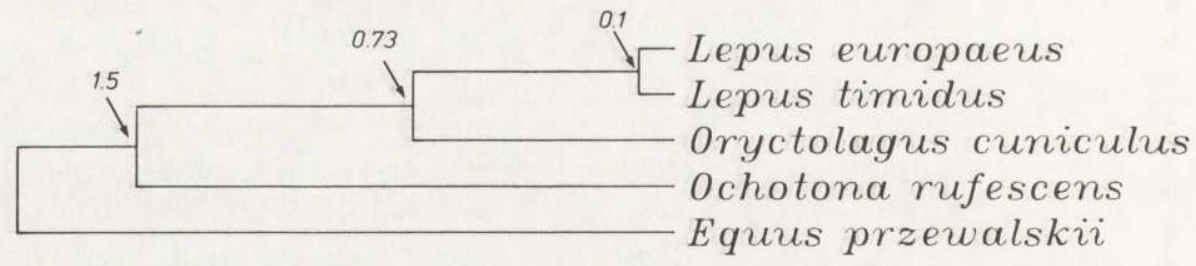

Fig. 1. Rooted dendrogram, showing genetic relationships in the Lagomorpha (Nei's 1978 D/UPGMA).

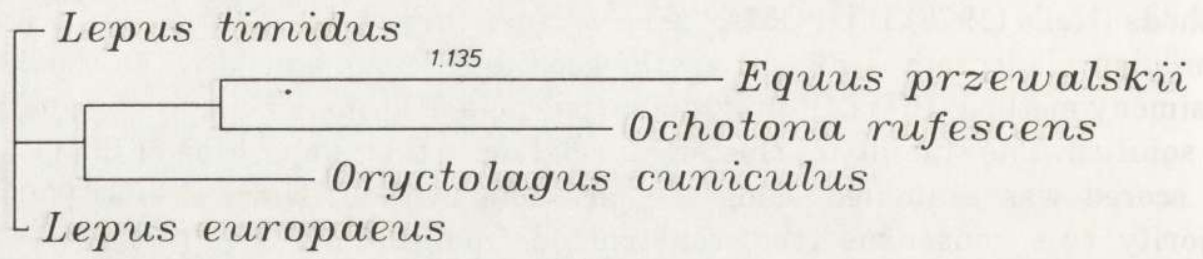

Fig. 2. Unrooted dendrogram, showing genetic relationships in the Lagomorpha (Nei's 1978 D/FitchMargoliash tree). 


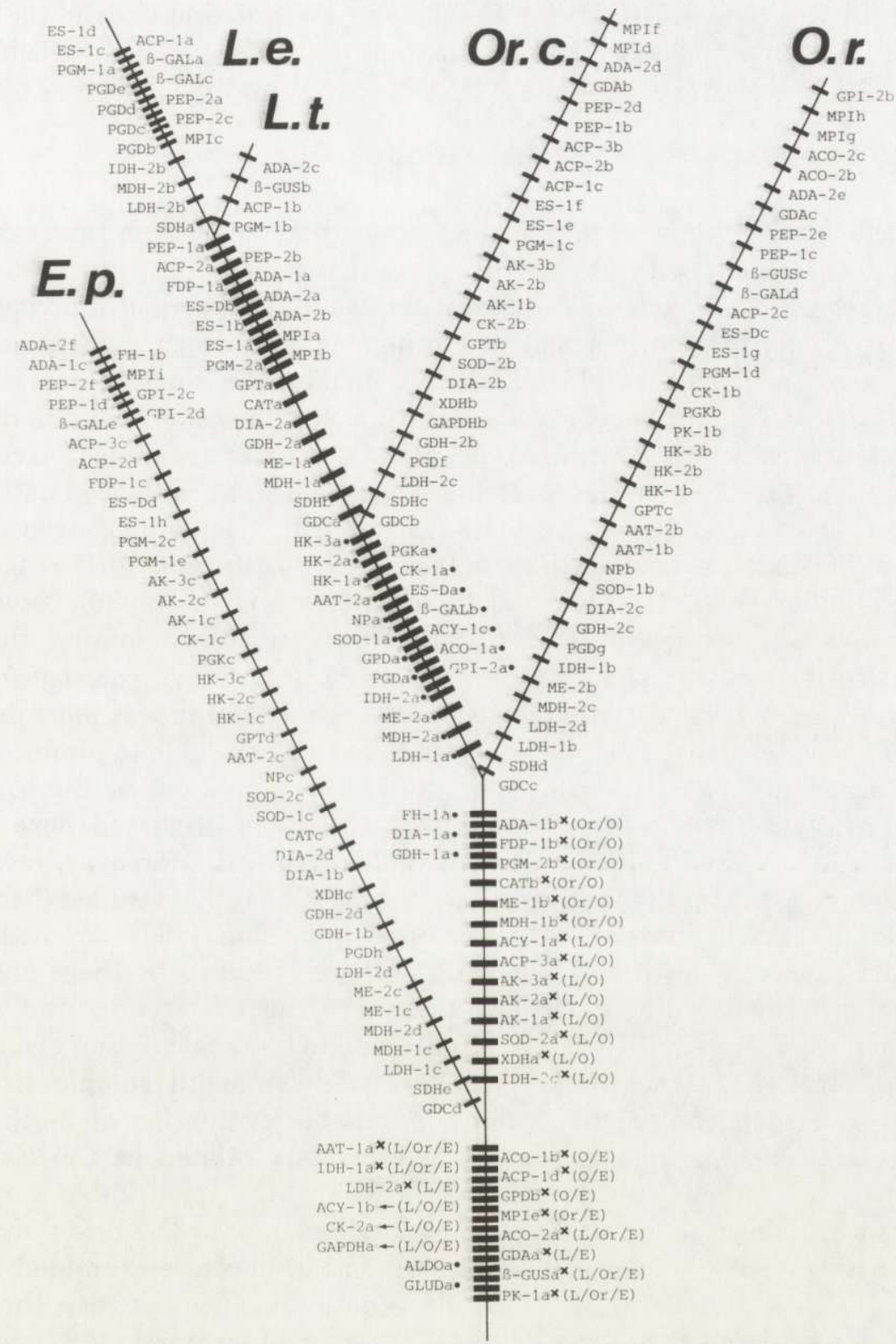

Fig. 3. Hennigian cladogram, showing genetic relationships in the Lagomorpha (constructed according to the criteria outlined in Hartl et al. 1990a). Isozymes = characters, allozymes = character states, dot $=$ character state symplesiomorphic or synapomorphic, arrow $=$ character state likely to be symplesiomorphic or synapomorphic, cross = character state possibly convergent (criteria are defined in Hartl et al. 1990a). L. e. = Lepus europaeus, L. t. = Lepus timidus, Or. c. = Oryctolagus cuniculus, O. $r .=$ Ochotona rufescens, $E . p .=$ Equus przewalshiii. The higher number of autapomorphies in $L . e$. in comparison to $L$. $t$. is probably due to the much larger number of individuals examined. 
fundamentally different approaches - comp. Hartl et al. 1990a, $1992: \mathrm{I}) \mathrm{t}=\mathrm{D} /(2 \alpha)$, whereby $\alpha=10^{-7}$ (Nei 1975), II) $0.1 \mathrm{D}=2.5 \mathrm{myr}$ (Wayne and O'Brin 1987). The respective divergence times between the taxa examined are shown in Table 4 .

\section{Discussion}

The biochemical-systematic relationships among the lagomorph taxa examined are in good agreement with the picture known from conventional systematics (comp. Diersing 1984, Nowak 1991). The use of small numbers of individuals for constructing numerical dendrograms in biochemical-systematic studies has been criticized, e. g. by Archie et al. (1989), but in our case fluctuations in allele frequencies due to sampling error could have some influence only on the distance between $L$. europaeus and L. timidus. All other distances are almost exclusively due to fixed alleles, which is confirmed by the remarkable consistency of dendrograms constructed by various methods and by the jackknife consensus tree.

The genetic distance between $L$. europaeus and L. timidus $(\mathrm{D}=0.098)$ is somewhat smaller than that detected by Bonhomme et al. (1986) between $L$. europaeus and $L$. granatensis $(\mathrm{D}=0.135)$ and considerably smaller than the D-values described by the same authors for $L$. europaeus / L castroviejoi (D = $0.355)$ and $L$. castroviejoi / L. granatensis $(0.334)$. This difference is most probably not related to the fact, that $L$. europaeus and $L$. timidus are able to produce fertile hybrids (Angermann 1983, Schröder et al. 1987). As pointed out by Bonhomme et al. (1986), allozyme genetic distances within the scope discussed here are no reliable indicator for the ability or inability to interbreed. Moreover, occasional hybridization also among the Iberian species is not to be fully excluded (Schneider and Leipoldt 1983). The larger D-values of Bonhomme et al. (1986) are rather due to the larger proportion of rapidly evolving proteins screened by these authors among the differential diagnostic loci there are the transferrin and several esterases not considered in the present study - and to their calculation of distances according to Nei (1972), which are not corrected for small sample sizes and commonly yield somewhat higher values. A reliable evaluation of biochemicalsystematic relationships among taxa being as closely related as the European Lepus species will be particularly valuab.e in view of the remarkable karyotypic conservatism (Robinson et al. 1983), but is possible only on the basis of a large and - most importantly - identical set of biochemical markers examined.

With a D-value (Nei 1978) of 0.712 , the genetic distance between the rabbit and the hare was found to be larger than that obtained by Hartl (1987), which is based on 38 loci and shows a D-value (Nei 1972) of 0.487 . This discrepancy can be fully explained by the fact, that - in contrast to Hartl (1987) - the isozymes $\mathrm{SDH}, \mathrm{XDH}, \mathrm{CAT}, \mathrm{AK}-2, \mathrm{AK}-3, \mathrm{PGM}-2$, and ADA were interpreted to show slightly different mobilities due to allelic differences at the corresponding loci between both genera in the present survey. The genetic distances of Ochotona from both 
Lepus and Oryctolagus are very similar, which is in agreement with the evolutionary conclusions drawn by Stock (1976), Corbet (1983), and Diersing (1984) from cytogenetic and morphological evidence. The horse was chosen as an outgroup, because among various mammalian orders discussed to share a common origin with the Lagomorpha, except for rodents, there is most evidence in favour of the Artiodactyla (or Ungulata in general - see Grillitsch 1990, for review). Regarding the genetic distances from the lagomorph taxa, a certain amount of bias due to problems in assessing the homology of loci and to homoplasy (comp. Fig. 3) must be considered (Buth 1984).

The divergence times between the Lepus species $(0.49 \mathrm{myr})$ and between Lepus and Oryctolagus (3.65myr) are in good agreement with divergence times obtained from other evidence (paleontological - Erbajeva 1981, Dawson 1981, mtDNA Biju-Duval et al. 1991), but only when they are calculated according to method I. Also the divergence time between the Leporidae and the Ochotonidae (37.5myr) fits well to estimates obtained from the literature (myoglobin sequencing - Dene et al. 1982, paleontology - Diersing 1984), but in this case only when calculated according to method II. The latter result suggests, that the estimate of $0.1 \mathrm{D}=$ $2.5 \mathrm{myr}$ used by Wayne and O'Brien (1987) in the Canidae gives a good estimate of time divergence also in the Lagomorpha, but only at a high taxonomic level. Among confamilial genera the estimates are much too high (Table 4), suggesting a generally more rapid rate of allozyme evolution in the Lagomorpha than in the Canidae. (The validity of this interpretation is corroborated by the very similar number and composition of isozyme loci screened in both surveys).

Apart from differences in allozyme evolutionary rates among mammalian orders, our data suggest considerable non-linearity of rates of allozyme substitution within one order. Similar results have been obtained already in the Artiodactyla and the Rodentia (comp. Hartl 1990, Hartl et al. 1990a, 1992). This non-linearity could be an artifact due to homoplasy, but could be also the result of accelerated rates of molecular evolution at low taxonomic levels. Homoplasy is to be expected mainly in rapidly evolving isozymes (comp. classification in Hartl et al. 1990a), which - with the exception of ACY-1 - show different alleles in Leporidae and Ochotonidae (see Fig. 3). Furthermore, the jackknife dendrograms confirm the topology of Figs. $1-3$ without a single exception. Thus, albeit not to be fully excluded, we do not think that homoplasy is sufficient to explain the observed non-linearity of divergence times.

As described by Hartl et al. (1990a, b) rapid cladogenesis in the presence of high levels of allozyme polymorphism within species could lead to the fixation of alternative alleles in the derived taxa and, thus, to a temporal acceleration of allozyme evolutionary rates by overriding the normal rate of codon substitution governed by mutation and genetic drift (Kimura 1987). In contrast to the Ochotonidae, the Leporidae are a thriving family with considerable rates of cladogenesis during the late Miocene and the Pliocene (Diersing 1984). However, in contrast to the predictions of Hartl et al. $(1990 \mathrm{a}, \mathrm{b})$, according to which derived 
taxa should exhibit higher distances and less variation than basal forms, comprehensive population genetic investigations in the brown hare (Hartl et al. 1989,1990 c, 1992, in preparation) and the rabbit (Richardson et al. 1980) revealed extensive allozyme polymorphism in both species. Moreover - at least in the brown hare - genetic distances among populations are close to zero. Nevertheless, in animals with high polymorphism, once reproductive isolation is established, considerable divergence can accumulate within a short period of time. This is corroborated by genetic distances among breeds of the domestic rabbit, reaching values which are higher than those found among subspecies of artiodactyls (comp. Peterka and Hartl 1992, Hartl and Markov, in press) only after several decades or centuries of separation (Peterka and Hartl 1992). Furthermore, in animals with rapid population growth after genetic bottlenecks, such as rodents and lagomorphs, genetic variation in derived species is not necessarily expected to be dramatically reduced (comp. Nei et al. 1975): in fact all lagomorphs studied so far are comparatively highly polymorphic (see Hartl et al. 1990c, for review).

In conclusion, an acceleration of molecular evolutionary rates during the radiation of the Leporidae seems to be possible and this may be the reason, why the estimation of divergence times by method I, being much less dependent on rate constancy among taxa than method II (Hartl 1990), yields the more reliable values at the species and genus level. A combined investigation of biochemical genetic variation and differentiation in the Leporidae, based on largely identical sets of isozymes is necessary for testing this hypothesis by tracing the evolutionary pathways of particular allozymes in a large number of subspecies, species and genera.

Acknowledgements: The authors are grateful to Dr. A. Puget, Centre National de la Recherche Scientifique Toulouse, for providing them with specimens of Ochotona rufescens.

\section{References}

Angermann R. 1983. The taxonomy of Old World Lepus. Acta Zool. Fennica 174: $17-21$.

Archie J. W., Simon C. and Martin A. 1989. Small sample size does decrease the stability of dendrograms calculated from allozyme frequency data. Evolution 43: 678 - 683 .

Baccus R., Ryman N., Smith M. H., Reuterwall C. and Cameron D. 1983. Genetic variability and differentiation of large grazing mammals. J. Mammal. 64: $109-120$.

Biju-Duval C., Ennafaa H., Dennebouy N., Monnerot M., Mignotte F., Soriguer R. C., El Gaaied A., El Hili A. and J.-C. Mounolou. 1991. Mitochondrial DNA evolution in lagomorphs: Origin of systematic heteroplasmy and organization of diversity in European rabbits. J. Mol. Evol. 33: 92 102.

Bonhomme F., Iskandar D., Thaler L. and Petter F. 1985. Electromorphs and phylogeny in muroid rodents. [In: Evolutionary Relationships Among Rodents - A Multidisciplinary Analysis. W. P. Luckett and J.-L. Hartenberger, eds]. Plenum Press, New York: 671 - 683.

Bonhomme F., Fernandez J., Palacios F., Catalan J. and Machordon A. 1986. Caracterisation biochimique du complexe d'especes du genre Lepus en Espagne. Mammalia 50: 495 - 506.

Brewer G. J. and Sing C. F. 1970. An Introduction to Isozyme Techniques. Academic Press, New York: $1-186$. 
Buth D. G. 1984. The application of electrophoretic data in systematic studies. Ann. Rev. Ecol. Syst. 15: $501-522$.

Corbet G. B. 1983. A review of classification in the family Leporidae. Acta Zool. Fennica 174: 11 - 15.

Csaikl F., Engel W. and Schmidtke J. 1980. On the biochemical systematics of three Apodemus species. Comp. Biochem. Physiol. 65B: $411-414$.

Dawson M. R. 1981. Evolution of the modern Lagomorphs. [In: Proceedings of the World Lagomorph Conference Held in Guelph, Ontario, August 1979. K. Myers and C. D. MacInnes, eds]. Univ. Guelph Publ,, Guelph: $1-8$.

Dene H., Goodman M. and McKenna M. C. and Romero-Herrera A. E. 1982. Ochotona princeps (pika) myoglobin: An appraisal of lagomorph phylogeny. Proc. Natl. Acad. Sci. USA 79: $1917-1920$.

Diersing V. E. 1984. Lagomorphs. [In: Orders and Families of Recent Mammals of the World. S. Anderson and J. Knox Jones Jr., eds]. John Wiley and Sons, New York: 241 - 254.

Erbajeva M. A. 1981. Late cenozoic Lagomorpha of Transbaikalia. [In: Proceedings of the World Lagomorph Conference Held in Guelph, Ontario, August 1979. K. Myers and C. D. MacInnes, eds]. Univ. Guelph Publ., Guelph: $53-55$.

Felsenstein J. 1985. Confidence limits on phylogenies: an approach using the bootstrap. Evolution 39: $783-791$

Georgiadis N. J., Kat P. W., Oketch H. and Patton J. 1990. Allozyme divergence within the Bovidae. Evolution 44: 2135 - 2149.

Goldman D., Giri P. R. and O'Brien S. J. 1989. Molecular genetic distance estimates among the Ursidae as indicated by one- and two-dimensional protein electrophoresis. Evolution 43: $282-$ 295.

Grillitsch M. 1990. Biochemisch-systematische Untersuchungen an ausgewählten Vertretern der Lagomorphen und dreier weiterer Plazentalia-Ordnungen. Unpublished PhD-thesis, Univ. Vienna.

Harris H. and Hopkins D. A. 1976. Handbook of enzyme electrophoresis in human genetics. Elsevier/ North Holland, Amsterdam. [Unnumbered pages]

Hartl G. B. 1987. Biochemical differentiation between the wild rabbit (Oryctolagus cuniculus L.), the domestic rabbit and the brown hare (Lepus europaeus Pallas). Z. zool. Syst. Evolut.-forsch. 25: $309-316$.

Hartl G. B. 1990. Genetic variation and biochemical-systematic relationships in Artiodactyla: results and hypotheses on the constancy of molecular evolutionary rates among proteins and taxa. (In: Proc. 2nd Symp. on the Genetics of Wild Animals, Gießen, in press).

Hartl G. B., Burger H., Willing R. and Suchentrunk F. 1990b. On the biochemical systematics of the Caprini and the Rupicaprini. Biochem. Syst. Ecol. 18: 175 - 182.

Hartl G. B., Göltenboth R., Grillitsch M. and Willing R. 1988a. On the biochemical systematics of the Bovini. Biochem. Syst. Ecol. 16: 575 - 579.

Hartl G. B. and Höger H. 1986. Biochemical variation in purebred and crossbred strains of domestic rabbits (Oryctolagus cuniculus L.). Genet. Research, Camb. 48: 27 - 34.

Hartl G. B. and Markov G. Genetic diversity in Bulgarian deer species. Acta Zool. Bulgarica (in press).

Hartl G. B., Markowski J., Kovacs G., Grillitsch M. and Willing R. 1990c. Biochemical variation and differentiation in the brown hare (Lepus europaeus) of Central Europe. Z. Säugetierk. 55: $186-193$.

Hartl G. B., Markowski J., Swiątecki A., Janiszewski T. and Willing R. 1992. Genetic diversity in the Polish brown hare Lepus europaeus, Pallas 1778: implications for conservation and management. Acta theriol. 37: $15-25$.

Hartl G. B., Suchentrunk F., Willing R. and Grillitsch M. 1989. Biochemisch-genetische Variabilität und Differenzierung beim Feldhasen (Lepus europaeus) in Niederösterreich. Wien. Tierärztl. Mschr. 76: $279-284$. 
Hartl G. B., Suchentrunk F., Willing R., Markowski J. and Ansorge H. 1992. Inconsistency of biochemical evolutionary rates affecting allozyme divergence within the genus Apodemus (Muridae: Mammalia). Biochem. Syst. Ecol. (in press).

Hartl G. B., Willing R., Grillitsch M. and Klansek E. 1988b. Biochemical variation in Mustelidae: are carnivores genetically less variable than other mammals. Zool. Anzeiger 221: $81-90$.

Hartl G. B., Willing R. and Suchentrunk F. 1990a. On the biochemical systematics of selected mammalian taxa: empirical comparison of qualitative and quantitative approaches in the evaluation of protein electrophoretic data. Z. zool. Syst. Evolut.-forsch. 28: $191-216$.

Kimura M. 1987. Die Neutralitätstheorie der molekularen Evolution. Paul Parey, Berlin und Hamburg: $1-303$.

Manlove M. N., Avise J. C., Hillestad H. O., Ramsey P. R., Smith M. H. and Straney D. O. 1975. Starch gel electrophoresis for the study of population genetics in the white-tailed deer. Proc. Ann. Conf. S. E. Assoc. Game and Fish Comm. 29: 393 - 403.

Nei M. 1972. Genetic distance between populations. Amer. Naturalist 106: $283-292$.

Nei M. 1975. Molecular Population Genetics and Evolution. Elsevier/North Holland, Amsterdam: $1-288$.

Nei M., Maruyama T., Chakraborty R. 1975. The bottleneck effect and genetic variability in populations. Evolution 29: 1- 10.

Nei M. 1978. Estimation of average heterozygosity and genetic distance from a small number of individuals. Genetics 89: $583-590$.

Nowak R. M. 1991. Walker's Mammals of the World. John Hopkins University Press, Baltimore and London. Vol. 1: 539 - 560 .

Peterka M. and Hartl G. B. 1992. Biochemical-genetic variation and differentiation in wild and domestic rabbits - On the significance of genetic distances, dendrograms and the estimation of divergence times in domestication studies. Z. zool. Syst. Evolut.-forsch. (in press).

Qavi H. and Kit S. 1980: Electrophoretic patterns of aminoacylase-1 (ACY-1) isozymes in vertebrate cells and histochemical procedure for detecting ACY-1 activity. Biochem. Genet. 18: 669 - 679.

Randi E., Fusco G., Lorenzini R., Toso S. and Tosi G. 1991. Allozyme divergence and phylogenetic relationships among Capra, Ovis and Rupicapra (Artiodactyla, Bovidae). Heredity 67: 281-286.

Richardson B. J., Rogers P. M. and Hewitt G. M. 1980. Ecological genetics of the wild rabbit in Australia II. Protein variation in British, French and Australian rabbits and the geographical distribution of the variation in Australia. Aust. J. Biol. Sci. 33: $371-383$.

Richardson B. J., Baverstock P. R. and Adams M. 1986. Allozyme Electrophoresis. A Handbook for Animal Systematics and Population Studies. Academic Press Australia, Sydney.

Robinson T. J. and Osterhoff D. R. 1983. Protein variation and its systematic implications for the South African Leporidae (Mammalia: Lagomorpha). Anim. Blood Grps. biochem. Genet. 14: $139-149$.

Robinson T. J., Elder F. F. B. and Chapman J. A. 1983. Karyotypic conservatism in the genus Lepus (order Lagomorpha). Can. J. Genet. Cytol. 25: 540 - 544.

Schneider E. and Leipoldt M. 1983. DNA-relationship within the genus Lepus in S. W. Europe. Acta Zool. Fennica 174: $31-33$.

Schröder J., Soveri T., Suomalainen H. A., Lindberg L.-A. and Van der Loo W. 1987. Hybrids between Lepus timidus and Lepus europaeus are rare although fertile. Hereditas 107: 185 - 189.

Selander R. K., Smith M. H., Yang S. Y., Johnson W. E. and Gentry J. B. 1971. Biochemical polymorphism and systematics in the genus Peromyscus. I. Variation in the old-field mouse (Peromyscus polionotus). Studies in Genetics Vol. 6, Univ. Texas Publ. 7103: 49-90.

Shaw C. R. and Prasad R. 1970. Starch gel electrophoresis of enzymes - a compilation of recipes. Biochem. Genet. 4: $297-320$. 
Siciliano M. J. and Shaw C. R. 1976. Separation and visualization of enzymes on gels. [In: Chromatographic and Electrophoretic Techniques, Vol. 2: Zone Electrophoresis. I. Smith, ed.]. William Heinemann, London: 185 - 209.

Simonsen V. 1982. Electrophoretic variation in large mammals II. The red fox, Vulpes vulpes, the stoat, Mustela erminea, the weasel, Mustela nivalis, the pole cat, Mustela putorius, the pine marten, Martes martes, the beech marten, Martes foina, and the badger, Meles meles. Hereditas 96: $299-305$.

Stock A. D. 1976. Chromosome banding pattern relationships of hares, rabbits, and pikas (order Lagomorpha) - A phyletic interpretation. Cytogenet. Cell Genet. 17: 78 - 88.

Taylor P. J., Campbell G. K., Meester J. A. J. and van Dyk D. 1991. A study of allozyme evolution in African mongooses (Viverridae: Herpestinae). Z. Säugetierk. 56: 135 - 145.

Thorup O. A., Strole W. B. and Leavell B. S. 1961. A method for the localization of catalase on starch gels. J. Lab. Clin. Med. 58: 122.

Vergnes H., Puget A. and Gouarderes C. 1974. Comparative study of red-cell enzyme polymorphism in the pika and the rabbit. Anim. Blood Grps. biochem. Genet. 5: 181- 188.

Wayne R. K. and O'Brien S. J. 1987. Allozyme divergence within the Canidae. Syst. Zoology 36: $339-355$.

Received 13 March 1992, accepted 10 May 1992. 